\title{
Front Matter: Volume 11020
}

, "Front Matter: Volume 11020," Proc. SPIE 11020, Smart Biomedical and Physiological Sensor Technology XVI, 1102001 (1 August 2019); doi:

$10.1117 / 12.2536306$ SPIE. Event: SPIE Defense + Commercial Sensing, 2019, Baltimore, MD, United 


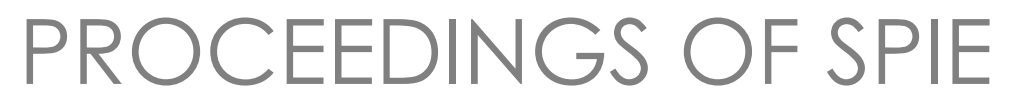

\title{
Smart Biomedical and Physiological Sensor Technology XVI
}

\author{
Brian M. Cullum \\ Douglas Kiehl \\ Eric S. McLamore \\ Editors
}

15-16 April 2019

Baltimore, Maryland, United States

Sponsored and Published by

SPIE

Volume 11020 
The papers in this volume were part of the technical conference cited on the cover and title page. Papers were selected and subject to review by the editors and conference program committee. Some conference presentations may not be available for publication. Additional papers and presentation recordings may be available online in the SPIE Digital Library at SPIEDigitalLibrary.org.

The papers reflect the work and thoughts of the authors and are published herein as submitted. The publisher is not responsible for the validity of the information or for any outcomes resulting from reliance thereon.

Please use the following format to cite material from these proceedings:

Author(s), "Title of Paper," in Smart Biomedical and Physiological Sensor Technology XVI, edited by Brian M. Cullum, Douglas Kiehl, Eric S. McLamore, Proceedings of SPIE Vol. 11020 (SPIE, Bellingham, WA, 2019) Seven-digit Article CID Number.

ISSN: 0277-786X

ISSN: 1996-756X (electronic)

ISBN: 9781510627055

ISBN: 9781510627062 (electronic)

Published by

SPIE

P.O. Box 10, Bellingham, Washington 98227-0010 USA

Telephone +1 3606763290 (Pacific Time) · Fax +1 3606471445

SPIE.org

Copyright (C) 2019, Society of Photo-Optical Instrumentation Engineers.

Copying of material in this book for internal or personal use, or for the internal or personal use of specific clients, beyond the fair use provisions granted by the U.S. Copyright Law is authorized by SPIE subject to payment of copying fees. The Transactional Reporting Service base fee for this volume is $\$ 18.00$ per article (or portion thereof), which should be paid directly to the Copyright Clearance Center (CCC), 222 Rosewood Drive, Danvers, MA 01923. Payment may also be made electronically through CCC Online at copyright.com. Other copying for republication, resale, advertising or promotion, or any form of systematic or multiple reproduction of any material in this book is prohibited except with permission in writing from the publisher. The CCC fee code is 0277$786 \mathrm{X} / 19 / \$ 18.00$.

Printed in the United States of America by Curran Associates, Inc., under license from SPIE.

Publication of record for individual papers is online in the SPIE Digital Library.

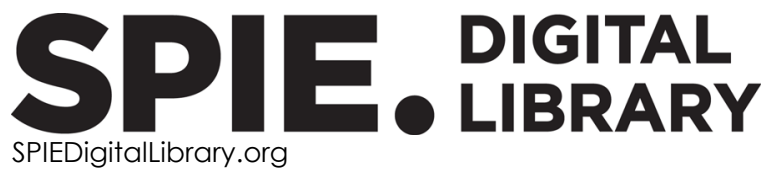

Paper Numbering: Proceedings of SPIE follow an e-First publication model. A unique citation identifier (CID) number is assigned to each article at the time of publication. Utilization of CIDs allows articles to be fully citable as soon as they are published online, and connects the same identifier to all online and print versions of the publication. SPIE uses a seven-digit CID article numbering system structured as follows:

- The first five digits correspond to the SPIE volume number.

- The last two digits indicate publication order within the volume using a Base 36 numbering system employing both numerals and letters. These two-number sets start with 00, 01, 02, 03, 04, 05, 06, 07, 08, 09, OA, OB ... 0Z, followed by 10-1Z, 20-2Z, etc. The CID Number appears on each page of the manuscript. 


\title{
Contents
}

\author{
$\checkmark \quad$ Authors \\ vii Conference Committee
}

\section{SESSION $1 \quad$ NOVEL MATERIALS FOR SMART SENSING}

1102002 Dielectric properties of $\mathrm{CaCU}_{3-x} \mathrm{Mg}_{\mathrm{x}} \mathrm{Ti}_{4} \mathrm{O}_{12}(\mathrm{x}=0.20$ and 0.50$)$ material synthesized by the semiwet route for energy storage capacitor (Invited Paper) [1 1020-1]

1102003 Mushroom Biotechnology: the rise of the fallen (Invited Paper) [1 1020-2]

1102005 Importance of lotus effect on surface sensing [1 1020-4]

1102006 Effect of processing on morphology of hydroxyapatites: bioactive glasses and crystalline composites [11020-5]

\section{SESSION 2 BIOSENSING TECHNIQUES ON THE HORIZON}

1102008 Quantitative laser speckle contrast imaging for presentation attack detection in biometric authentication systems [1 1020-7]

1102009 Thermally-induced optical reflection of sound (THORS) for photoacoustic sensing [1 1020-8]

11020 OA Determining driver nodes in dynamic signed biological networks [1 1020-9]

$11020 \mathrm{OB} \quad$ Topographic imaging of an absorbing object in a tissue-like scattering medium using a single source-detector pair [1 1020-10]

\section{SESSION $3 \quad$ BIORECOGNITION/BIOREACTIVE PLATFORMS FOR SENSING}

11020 OE Development of army relevant integrated photonics MIP platform [1 1020-13]

11020 OG Electric fields assisted fluorescence enhancement for microRNA biomarker detection in serum samples: strategies for combating cancer, obesity and addiction to opioid (Invited Paper) [11020-15]

$11020 \mathrm{OH} \quad$ Guided-mode resonance sensing of neuropeptide-Y with a sandwich assay achieving $\mathrm{pg} / \mathrm{mL}$ detection (Invited Paper) [1 1020-16] 
11020 OK Model reduction of structural biological networks by cycle removal [1 1020-19]

\section{SESSION $5 \quad$ RECENT ADVANCES IN WEARABLES}

11020 OM Ruggedized peptide receptors for soldier health and performance monitoring [11020-21]

11020 ON Printable transistors for wearable sweat sensing (Invited Paper) [1 1020-22]

1102000 Predicting limits of detection in real-time sweat-based human performance monitoring [11020-23]

11020 OP Electronic tattoos: the most multifunctional but imperceptible wearables [1 1020-24]

$110200 Q \quad$ Blast wave sensing from flexible piezoelectric materials [1 1020-25]

11020 OR Smart wristband with integrated chemical sensors for detecting glucose levels using breath volatile organic compounds [11020-26]

\section{SESSION 6 TOWARDS THE CLINIC/HOME}

11020 OT Flexible polyimide based 34-channel electrode arrays for mouse EEG measurement [1 1020-28]

11020 OV Recognition of imagined speech using electroencephalogram signals [1 1020-30]

POSTER SESSION

$110200 Z$ Effect of coil size on transcranial magnetic stimulation (TMS) focality [1 1020-38]

iv 


\section{Authors}

Numbers in the index correspond to the last two digits of the seven-digit citation identifier (CID) article numbering system used in Proceedings of SPIE. The first five digits reflect the volume number. Base 36 numbering is employed for the last two digits and indicates the order of articles within the volume. Numbers start with 00, 01, 02, 03, 04, 05, 06, 07, 08, 09, OA, 0B...0Z, followed by 10-1Z, 20-2Z, etc.

Abdallah, Mohammad G., $\mathrm{OH}$

Abd-Almageed, Wael, 08

Allen, Jeffery W., $\mathrm{OH}$

Allen, Monica S., $\mathrm{OH}$

Arnold, Bradley, 05, 06

Bagherzadeh, Hedyeh, $0 Z$

Bhardwaj, Divyanshu, 02

Bickford, Justin R., OE

Boubin, M., OR

Bowman, Eric, 06

Brennecka, Geoff, $0 Q$

Buchanan-Vega, Joseph A., $\mathrm{OH}$

Cho, Pak S., OE

Choa, Fow-Sen, 05, 06, 0T, 0 Z

Chowdhury, Fatima Nafisa, OT

Cooper, Christopher, 05

Coppock, Matthew B., OM

Cullum, Brian M., 05, 06, 09

Farrell, Mikella E., OE

Fragkos, M. A., OB

Gimlin, Susanne, $\mathrm{OH}$

Gordaninejad, Faramarz, $0 Q$

Habif, Jonathan L., 08

Harold, C., OR

Harris, Jonathan K., ON, 00

Holthoff, Ellen L., 09, OE

Hussein, Mohamed, 08

Jagannathan, Arun, 08

Jeong, Hyoyoung, OP

Kavlicoglu, Barkan, $O Q$

Kazal, Daniel S., 09

Kelly, Lisa, 05, 06

Lawrence, L., OR

Lee, Kyu J., $\mathrm{OH}$

Lee, Y., 02

Lobo, Mary Kay, OT

Lu, Nanshu, OP

Magnusson, Robert, $\mathrm{OH}$

Mahato, D. K., 02

Mandal, K. D., 02, 06

Mannschreck, Richard, $0 Q$

McAdams, Joel, 06

Mertiri, M., OB

Meyer-Baese, Anke, OA, OK

Meyer-Baese, Lisa, 0A

Meyer-Baese, Uwe, OK

Mohebali, Behshad, OA, OK

Muzinich, Blake, $O Q$

Nam, Hyungwoo, OT
Nawarathna, Dharmakeerthi, OG

Neubig, Theresa, OV

Pellegrino, Paul M., OE

Pinker, Katja, OA, OK

Prasad, Narasimha, 05

Rai, U. S., 02

Raptis, N., OB

Ratcliff, Erin L., ON, 00

Roditi, E., OB

Rosa, Christopher, $0 Q$

Rudolph, Melanie, ON, 00

Sellami, Loviza, OV

Shrestha, S., OR

Singh, Laxman, 02

Singh, M. P., 03

Singh, N. B., 02, 05, 06

Singh, Shruti, 06

Solimine, Philip, OA, OK

Sood, Rachit, OT

Sova, Stacey, 05

Spinoulas, Leonidas, 08

Stratis-Cullum, Dimitra N., OM

Su, Ching Hua, 06

Sun, Claire, 08

Syvridis, D., OB

Tahmassebi, Amirhessam, OA, OK

Velmanickam, Logeeshan, OG

Weidanz, Debra Wawro, $\mathrm{OH}$

Wenner, Brett R., $\mathrm{OH}$

Willens, Kyle, $O Q$ 
Proc. of SPIE Vol. 11020 1102001-6

\section{Downloaded From: https://www.spiedigitallibrary.org/conference-proceedings-of-spie on 26 Apr 2023
Terms of Use: https://www.spiedigitallibrary.org/terms-of-use}




\title{
Conference Committee
}

\author{
Symposium Chairs
}

Jay Kumler, JENOPTIK Optical Systems, LLC (United States)

Ruth Moser, Air Force Research Laboratory (United States)

Symposium Co-chair

John Pellegrino, Electro-Optical Systems Laboratory, Georgia Institute of Technology (United States)

Conference Chairs

Brian M. Cullum, University of Maryland, Baltimore County (United States)

Douglas Kiehl, Eli Lilly and Company (United States)

Eric S. McLamore, University of Florida (United States)

Conference Program Committee

Karl S. Booksh, University of Delaware (United States)

Alper Bozkurt, North Carolina State University (United States) Jonathan C. Claussen, lowa State University (United States)

Matthew B. Coppock, U.S. Army Research Laboratory (United States)

Mikella E. Farrell, U.S. Army Research Laboratory (United States)

Moinuddin Hassan, U.S. Food and Drug Administration (United States)

Ellen L. Holthoff, U.S. Army Research Laboratory (United States)

Ilko K. Ilev, U.S. Food and Drug Administration (United States)

K. D. Mandal, Institute of Technology, Banaras Hindu University (India) Heather McCauley, U.S. Food and Drug Administration (United States)

Olga S. Ovchinnikova, Oak Ridge National Laboratory (United States)

T. Joshua Pfefer, U.S. Food and Drug Administration (United States)

Shiv K. Sharma, University of Hawai'i (United States)

Narsingh B. Singh, University of Maryland, Baltimore County (United States)

Dimitra N. Stratis-Cullum, U.S. Army Research Laboratory (United States)

Michael Weinrich, University of Maryland, Baltimore Country (United States) 


\section{Session Chairs}

$1 \quad$ Novel Materials for Smart Sensing

Mohan Singh, University of Allahabad (India)

2 Biosensing Techniques on the Horizon

Jonathan C. Claussen, lowa State University of Science and Technology (United States)

Brian M. Cullum, University of Maryland, Baltimore County (United States)

3 Biorecognition/Bioreactive Platforms for Sensing

Mikella E. Farrell, U.S. Army Research Laboratory (United States)

Dimitra N. Stratis-Cullum, U.S. Army Research Laboratory (United States)

$4 \quad$ Pathogen Sensing/Food Monitoring

Eric S. McLamore, University of Florida (United States)

Jonathan C. Claussen, lowa State University of Science and Technology (United States)

5 Recent Advances in Wearables

Matthew B. Coppock, U.S. Army Research Laboratory (United States)

Douglas Kiehl, Eli Lilly and Company (United States)

6 Towards the Clinic/Home

Douglas Kiehl, Eli Lilly and Company (United States) 